\title{
FINTECH SYARIAH ALTERNATIF PENDANAAN UMKM PADA MASA PANDEMI COVID-19 DI INDONESIA
}

\author{
Yuddy Slamet Rasidi \\ Magister Manajemen Teknologi, Institut Teknologi Sepuluh Nopember \\ yuddy.rasidi@gmail.com \\ Catur Setio Budi \\ Magister Manajemen Teknologi, Institut Teknologi Sepuluh Nopember \\ catursetiobudi@gmail.com \\ Prasetyo Arie Hatmoko \\ Magister Manajemen Teknologi, Institut Teknologi Sepuluh Nopember \\ askprasetyoarie@gmail.com
}

\begin{abstract}
Abstrak
Paper ini bertujuan untuk memaparkan alternatif pendanaan menggunakan Financial Technology (Fintech) syariah untuk penggiat UMKM yang terkena dampak dari Pandemi Covid-19 di Indonesia. Metode yang digunakan dalam penelitian ini adalah deskriptif analisis dengan pendekatan kualitatif dimana pendekatan ini menjelaskan penelitian pada suatu subjek. Sumber data merupakan data sekunder yang diperoleh melalui studi kepustakaan berupa jurnal, artikel berita, dan buku-buku yang berkaitan dengan penelitian. Data-data yang telah terkumpul akan diklasifikasikan, lalu diverifikasi apakah sesuai dengan penelitian dan selanjutnya dianalisis. Hasil penelitian menemukan bahwa selama masa Pandemi Covid-19 omset UMKM mengalami penurunan dan banyak UMKM yang tidak memiliki cadangan modal usaha. Fintech syariah bisa menjadi solusi permodalan masyarakat khususnya UMKM dan Fintech dapat membantu pengefektifan bantuan pembiayaan pemerintah dan sebagai parameter yang menunjukkan peningkatan literasi keuangan masyarakat, khususnya UMKM dalam mengakses pembiayaan serta transaksi keuangan.
\end{abstract}

Kata kunci: Covid-19, UMKM, Financial Technology (Fintech) Syariah

\begin{abstract}
This paper aims to describe alternative funding using Islamic Financial Technology (Fintech) for MSME activists affected by the Covid-19 Pandemic in Indonesia. The method used in this research is descriptive analysis with a qualitative approach where this approach describes research on a subject. Sources of data are secondary data obtained through library research in the form of journals, news articles, and books related to research. The data that has been collected will be classified, then verified whether it is in accordance with the research and then analyzed. The results of the study found that during the Covid-19 Pandemic the turnover of MSMEs decreased and many MSMEs did not have business capital reserves. Sharia fintech can be a solution for community capital, especially MSMEs and Fintech can help make government financing assistance effective and as a parameter that shows an increase in public financial literacy, especially MSMEs in accessing financing and financial transactions.
\end{abstract}

Keyword: Covid-19, UMKM, Financial Technology Syariah. 


\section{Pendahuluan}

Pandemi Covid-19 yang pertama kali mewabah di Wuhan, China pada November 2019, kemudian menyebar masuk ke Indonesia pada awal Maret 2020. Covid-19 menyebabkan berbagai dampak pada seluruh lini kehidupan di Indonesia, dampak tersebut berlangsung hingga saat ini. Imbasnya juga sangat terasa pada perekonomian di Indonesia, khususnya pada Usaha Mikro Kecil dan Menengah (UMKM), walaupun sebenarnya perusahaan-perusahaan besar pun terdampak dan banyak yang mengurangi karyawan bahkan menutup usaha mereka karena omset usaha yang terus menurun.

Menurut hasil survei yang dilakukan Mandiri Investasi pada bulan Mei 2020 dengan sample 319 responden, UMKM di beberapa tempat yang tersebar di Indonesia mengatakan bahwa omset usaha mereka mengalami penurunan hingga lebih dari 50 persen. Jadi sekitar 70 persen responden untuk yang offline kemudian 66 persen untuk yang online (Yoga, 2020).

Untuk memulihkan usaha UMKM tersebut tentu membutuhkan suntikan dana agar dapat bergerak kembali dan meningkatkan omset mereka. Mengajukan pembiayaan pada bank cukup sulit karena bank pun akan mengacu pada tingkat kesehatan usaha mereka, dengan keadaan omset usaha yang turun maka bank akan sulit mengabulkan pinjaman yang diajukan oleh UMKM.

Badan program pembangunan Persatuan Bangsa-Bangsa (PBB) atau United Nations Development Programme (UNDP) menjelaskan sebagian penggiat usaha mikro di Indonesia, untuk pendanaan bisnisnya masih bergantung kepada sumber pendanaan keluarga.UNDP menyebutkan dalam laporan terbarunya bahwa sebanyak 36.7 persen pelaku usaha mikro di Indonesia bergantung pada sumber pendanaan internal yaitu keluarga. Sedangkan 33.2 persen usaha mikro lainnya bergantung pada pendanaan bank (Cakti, 2021).

Salah satu solusi yang dapat dilakukan oleh Teknologi Finansial Syariah. Menurut data World Population Review, jumlah penduduk muslim di Tanah Air tahun 2020 mencapai 229 juta jiwa atau $87.2 \%$ dari total penduduk 273,5 juta jiwa (Barus, 2021). Ini potensi yang baik untuk Teknologi Finansial Syariah sebagai alternatif pendanaan.

Sejalan dengan pernyataan Dewan Syariah Nasional - Majelis Ulama Indonesia (DSNMUI) untuk mempercepat peningkatan pasar keuangan syariah di Indonesia, kerjasama didorong antara perusahaan teknologi keuangan dan perbankan syariah. Bahkan DSN-MUI memberikan landasan kuat untuk pengembangan Teknologi Finansial Syariah Indonesia dengan mengeluarkan Fatwa Nomor 117/DSN-MUI/II/2018 mengenai Layanan Pembiayaan Berbasis Teknologi Informasi Berdasarkan Prinsip Syariah, dan acuan lain, mengacu POJK 77/2016.

Eksistensi dari Pandemi Covid-19 dan perkembangan vaksinasi Covid-19 di Indonesia menunjukkan masih banyak potensi yang masih eksis bahkan muncul di Indonesia di bidang Teknologi Financial. Penelitian ini bertujuan untuk menjelaskan peluang pendanaan alternatif menggunakan Teknologi finansial syariah, penelitian ini memakai pendekatan kualitatif dan metode deskriptif, dan dikembangkan dengan menggunakan studi pustaka atau Pendekatan studi pustaka berupa buku, jurnal ilmiah dan platform internet.

\section{Metode}

Penelitian ini menggunakan metode deskriptif-analisis dengan pendekatan kualitatif yang menjelaskan penelitian pada suatu subjek. Data yang dikumpulkan merupakan data sekunder, teknis analisis dan pengumpulan data dilakukan dengan kajian pustaka sebagai data pendukung 
penelitian secara ilmiah. Data yang dianalisis berbentuk jurnal, karya ilmiah, artikel dan sumber lain yang di butuhkan. Hasil data literatur tersebut dapat membantu dalam mengidentifikasi apakah Fintech syariah bisa digunakan sebagai alternatif pendanaan UMKM di masa pandemi Covid-19 di Indonesia.

\section{Hasil dan Pembahasan}

Pada bagian ini akan dibahas mengenai nasib UMKM selama pandemi Covid-19, peran penting Financial Technology (Fintech) syariah untuk pendanaan UMKM di Indonesia, keberadaan Fintech syariah guna penggiat UMKM, dan Fintech syariah jadi alternatif solusi permodalan UMKM di masa pandemi.

\subsection{Nasib UMKM Selama Pandemi Covid-19}

Pandemi Coronavirus Disease atau Covid-19 berlangsung sepanjang tahun 2020 hingga saat ini sudah diparuh tahun 2021 belum ada tanda-tanda akan berakhir, justru semakin mewabah dengan varian baru dari virus yang berasal dari Wuhan ini. Dengan munculnya virus corona ini berdampak besar terhadap perubahan perilaku masyarakat Indonesia dan tentunya sangat bepegaruh terhadap Ekomomi di Indonesia.

Geliat ekonomi masyarakat Indonesia menjadi terbatasi dan berkurang dan secara otomatis mengakibatkan pendapatan masyarakat Indonesia menurun. Hasil Survei Sosial Demografi Dampak Covid-19 tahun 2020 yang dilakukan Badan Pusat Statistik (BPS) menunjukkan tren menurunnya Produk Domestik Bruto (PDP) selama tahun 2020, secara berturut-turut penurunan terjadi 2,47 persen di triwulan pertama 2020 dan mengalami penurunan 4,19\% pada triwulan kedua tahun 2020. Berdasarkan survei tiga sektor yang paling berdampak adalah perdagangan besar dan eceran, reparasi mobil dan sepeda motor, sektor transportasi dan pergudangan, serta sektor penyediaan akomodasi dan makan minum yang mana banyak didominasi oleh UMKM.

Usaha mikro kecil menengah atau (UMKM) secara umum adalah kegiatan usaha ekonomi produktif yang dimiliki perorangan maupun badan usaha sesuai dengan kriteria yang atur oleh Undang-undang UU No. 20 tahun 2008. Dari definisinya terdapat batasan-batasan, mulai dari usaha mikro, kecil dan menengah yaitu di lihat dari batasan besaran aset dan omset. Selama pandemi Covid-19 sebagian besar UMKM tergerus pendapatannya dan tidak sedikit yang mengalami kesulitan dalam menjalankan usaha yang dikarenakan tidak memiliki cadangan modal usaha.

Menurut Menteri Koperasi dan Usaha Kecil Menengah (UKM) Teten Masduki, mengutarakan bahwa tahun ini merupakan tahun yang sangat berat bagi para pelaku Usaha Mikro, Kecil dan Menengah (UMKM), penanganan COVID-19 menjadi sangat penting untuk nasib UMKM untuk terus bertahan ke depannya. Kondisi pandemi saat ini lebih menyulitkan para penggiat UMKM bila dibandingkan dengan krisis yang terjadi pada tahun 1998 dan 2008, karena ada pembatasan protokol kesehatan dan pergerakan atau pendistribusian sehingga sangat berdampak pada sisi Supply dan Demand (Rizky \& Kencana, 2020).

Kondisi saat ini jauh berbeda disaat pandemi Covid-19 menjadi bencana seluruh negara di dunia tidak terkecuali Indonesia. UMKM tak lagi setangguh dulu, banyak yang lumpuh, dipertanyakan keandalannya dalam menopang perekonomian negara. Pangsa pasar UMKM, berupa kebutuhan masyarakat sehari-hari, baik sandang maupun pangan, semakin menyempit. Di dalam ruang gerak yang sudah teramat sempit, aneka produk yang dhasilkan tidak menjadi 
transaksi yang mampu menggerakkan ekonomi nasional dan terjadi perputaran uang. Walaupun masih ada yang dapat bertahan, dengan beradaptasi dengan kondisi pandemi namun jumlahnya sangat kecil dibanding dari puluhan juta penggiat UMKM (Simanjorang, 2020).

\subsection{Peran Penting Financial Technology Syariah Untuk Pendanaan UMKM di Indonesia}

Dalam kondisi pandemi Covid-19 saat ini, secara tidak langsung memaksa kita untuk melek teknologi. Apalagi di era digitalisasi pemanfaatan teknologi menjadi sebuah keniscayaan untuk kemudahan dan efisiensi. Hal ini juga terjadi pada sektor keuangan yang terus berbenah dan berinovasi dalam teknologi keuangan untuk meraup pangsa pasar dan efisiensi biaya. Digitalisasi gencar terjadi pada sektor perbankan dengan mengimplementasikan Financial Technology (Fintech) dengan tujuan memberikan kemudahan nasabahnya dan berupaya meningkatkan kepuasan pelanggan.

Fintech adalah model pembiayaan baru yang telah merubah model bisnis dari konvensional ke digitalisasi, yang sebelumnya transaksi harus bertatap muka sekarang bisa melakukan transaksi online dengan waktu yang relatif sangat singkat tanpa tatap muka. Menurut pengamat Fintech, Hasnil Fajri mengutarakan sejak awal tahun 2018 pengguna smartphone di Indonesia diperkirakan sekitar 177,9 juta orang, dan 132,7 juta pengguna diantaranya merupakan pengguna internet. Dengan kondisi seperti itu Fintech menjadi primadoma baru untuk bertransaksi keuangan secara digital.

Berdasarkan data Asosiasi Fintech Indonesia (Aftech), pengguna layanan Fintech terbanyak adalah kelompok para muda generasi milenial berusia 25-35 tahun, kelas menengah dengan gaji Rp5 juta sampai Rp15 juta per bulan. Hal ini terjadi karena kelompok ini sudah melek teknologi. Fakta lain, bahwa melihat syariah masih kuno dan ribet, dengan hadirnya Fintech syariah bisa merubah stigma terebut di mana Fintech syariah itu memudahkan dan sejalan dengan waktu pada suatu saat nanti industri keuangan syariah akan berkembang dengan inovasi teknologi yang sepadan dengan Fintech konvensional.

Namun data berbicara, di tahun 2019 target indeks inklusi keuangan masih di bawah target 75 persen yang mana ini menunjukkan rendahnya pengetahuan keuangan masyarakat Indonesia dan ini harus ditingkatkan dengan inovasi-inovasi teknologi keuangan. Dengan hadirnya Fintech berserta inovasi-inovasinya, membawa angin segar bagi masyarakat Indonesia yang selama ini kesulitan. Melalui Fintech bisa menghubungkan penggiat UMKM dengan layanan keuangan yang sebelumnya belum terjamah oleh layanan keuangan perbankan. Akses layanan keuangan bukan barang mewah lagi. Transfer uang, mencari produk keuangan bank dan non-bank, sampai pengajuan pinjaman kini bisa dilakukan jarak jauh hanya dalam hitungan sekejap mata saja. Kemudahan ini semakin mengangkat sektor Fintech dalam perannya menjalankan ekonomi nasional dan terjadinya transformasi dari konvensional ke era digital (Ariyanti, 2019).

Peluang berkembangnya ekonomi dan keuangan syariah termasuk Fintech syariah di indonesia adalah sangat besar. Hal ini dikarenakan negara Indonesia adalah negara dengan jumlah penduduk yang menganut agama islam terbesar di dunia. Pada dasarnya secara fungsi tidak ada bedanya antara Fintech Syariah dan Fintech konvensional yaitu sama-sama memberikan layanan keuangan. Namun hal yang membedakan diantara keduanya adalah pada akadnya saja dimana Fintech syariah mengikuti aturan syariat Islam. Bahkan payung hukumnya 
sama yaitu berlandaskan pada Peraturan Otoritas Jasa Keuangan (POJK) nomor 77 Tahun 2016 tentang Layanan Pinjam Meminjam Uang Berbasis Teknologi Informasi. Selain itu Fintech syariah juga merujuk Fatwa Dewan Syariah Nasional Majelis Ulama Indonesia No. 117 tahun 2018 yaitu Mengenai Layanan Pembiayaan Berbasis Teknologi Informasi Berdasarkan Prinsip Syariah.

Selain peraturan ada aspek lain yang perlu diperhatikan untuk mengembangkan bisnis Fintech di Indonesia yaitu:

a. Perizinan;

b. AD/ART perusahaan;

c. Perjanjian/kontrak;

d. Bukti kepemilikan asset;

e. Sengketa hukum;

f. Perpajakan.

Keenam hal tersebut perlu diperhatikan oleh pengembang bisnis Fintech di Indonesia agar bisnis Fintech berjalan dengan baik. Terdapat juga manfaat Fintech Syariah di ini, diantaranya:

a. Membantu para pelaku UMKM

Banyaknya persyaratan yang diajukan oleh bank dalam pengajuan pendanaan untuk UMKM dan lebih rumit dibandingkan Fintech, hal ini membuat Fintech syariah menjadi jawaban untuk pelaku UMKM dalam mendapatkan pendanaan, karena lebih mudah, murah, cepat dan efisien.

b. Bebas Riba

Fintech syariah mengedepankan tiga prinsip syariah yang terbebas dari tiga "Maghrib", yaitu Maysir, Gharar, dan Riba. Ini yang membuat Fintech syariah lebih aman karena tidak ada bunga. Fintech syariah mendapatkan keuntungan dari istilah yang dikenal dalam syariat Islam yaitu bagi hasil dari keuntungan yang didapat. Pembagian keuntungan maupun risiko dilakukan dan dipertaruhkan bersama-sama. Maka dalam ini UMKM selaku penerima pendanaan tidak perlu khawatir jika usaha tidak berjalan lancar dan gagal membayar modal awal.

c. Menguntungkan banyak pihak

Peranan Fintech adalah sebagai jembatan antara pemilik dana dengan pihak yang memerlukan dana sehingga terjadi keseimbangan antara keduanya. Sehingga Fintech bukan hanya menguntungkan kalangan mengengah ke atas karena mendapat keuntungan, dan tetapi juga mensejahterakan ekonomi masyarakat penggiat UMKM.

d. Proses yang mudah

Fintech sangat mudah diakses secara online dimanapun dan kapanpun hanya dengan memanfaatkan smartphone dan internet, transaksi keuangan melalui Fintech sudah bisa dilakukan.

e. Lebih Aman

Dengan bebas riba Fintech syariah lebih aman karena adanya bunga hanya akan menguntungkan salah satu pihak dan merugikan pihak lain. Selain itu ada aturan yang wajib diikuti dalam bisnis Fintech syariah yaitu wajib mengikuti aturan dari DSN-MUI dan OJK (Techfor Id, 2019). 
Dilihat dari pentingnya Fintech Syariah, maka dengan resminya OJK menyetujui Asosiasi Fintech Syariah Indonesia (AFSI) sebagai asosiasi Fintech syariah yang ditunjuk oleh OJK untuk industri teknologi finansial syariah Group Inovasi Keuangan Digital (GIKD). Dengan penunjukan ini diharapkan fintech Syariah bisa berkembang dan terus berinovasi dalam menghadapi pasar digital di Indonesia. Hal ini menjadi titik penting melihat Fintech Syariah bisa dikembangkan secara tersendiri dan bisa besaing dengan Fintech konvensional lainnya. Dengan penunjukan AFSI oleh OJK ini diharapkan semakin memberikan kenyamanan pelaku UMKM karena pengawasan praktik pembiayaan dan transaksi keuangan lain semakin banyak yang mengawasi. Selain itu ada kejelasan aturan industri teknologi financsial Syariah di Indonesia (Evandio, 2020).

\subsection{Keberadaan Fintech Syariah Guna Penggiat UMKM}

Harapan bagi para pelaku Usaha Kecil Mikro dan Menengah (UMKM) dalam mengembangkan usahanya, salah satunya yaitu dapat dengan mudah mengakses pembiayaan. Fintech berupa P2P (Peer To Peer) lending adalah jawaban untuk penggiat UMKM yang Unbankable menjadi mudah terakses. Pada akhirnya, Fintech ini bisa meningkatkan kapasitas UMKM dan mengalami peningkatan. Untuk mendukung dan menunjang pelaku UMKM, pemerintah mempunyai sejumlah program. Program-program tersebut diantaranya Kredit Usaha Rakyat (KUR) yang diluncurkan pada tahun 2007 merupakan salah satu program pemerintah, dimana realisasi penyaluran KUR maupun debiturnya terus meningkat (Rizal et al., 2019).

Dalam rangka mempercepat pengembangan UMKM sejalan dengan akan diterbitkannya RUU Cipta Lapangan Kerja, Komite Kebijakan Pembiayaan bagi UMKM memutuskan untuk merubah kebijakan KUR yang lebih berpihak kepada rakyat sebagai berikut:

a. Suku bunga turun dari $7 \%$ menjadi $6 \%$;

b. Total plafon KUR ditingkatkan dari 140 Triliun menjadi 190 Triliun pada tahun 2020, dan akan ditingkatkan bertahap sampai dengan Rp325 Triliun pada tahun 2024;

c. Peningkatan plafon KUR Mikro dari Rp25 juta menjadi Rp50 juta per debitur (Rakyat, 2020).

Menurut data terbaru OJK atau Otoritas Jasa Keuangan (per Agustus 2019) dari total 127 startup Fintech yang terdaftar, hanya sembilan yang merupakan Fintech syariah. Fintech syariah tersebut diantaranya Ammana, Alami Sharia, Investree Syariah, Dana Syariah, Danakoo Syariah, Qazwa, Duha Syariah, Syarfi, dan Bsalam (Fachrizal, 2019). Data dari OJK per 30 Maret 2021, diketahui total penyelenggara Fintech peer to peer lending yang terdaftar dan berizin sebanyak 147 perusahaan dan 11 diantaranya adalah Fintech Syariah (Keuangan, 2021).

Perkembangan teknologi menjadikan layanan keuangan menjadi lebih murah, cepat dan mudah. Ketiga elemen ini yang sulit didapat oleh pelaku UMKM ketika datang ke bank. Di sinilah peranan Fintech dalam memberikan solusi bagi pelaku usaha UMKM. Tantangan paling mendasar untuk memaksimalkan peranan Fintech dalam mendukung UMKM dimasa akan datang adalah akses masyarakat Indonesia terhadap layanan keuangan. Menurut survei yang dilakukan Otoritas Jasa Keuangan, hanya 67,8 persen dari masyarakat Indonesia yang sudah menggunakan produk keuangan, hal ini berarti masih ada 32,2 persen yang belum menggunakan produk keuangan (Rizal et al., 2019). 
Ekonomi terbesar di Asia Tenggara adalah di Indonesia, UMKM menyumbang 60 persen dari perekenomian negara dan menyerap 97 persen tenaga kerja. Walaupun ada lebih 60 juta UMKM di Indonesia, hanya 12 persen yang mendapatkan pembiayaan atau pinajam bank. Pandemi Covid-19 memperparah situasi untuk pelaku UMKM, hampir 50 persen atau sekitar 30 juta UMKM terpaksa harus tutup sementara. Hal ini dikarenakan permintaan pasar yang turun. Hadirnya Fintech platform akan sangat membantu karena Fintech adalah kombinasi layanan keuangan dan teknologi yang dapat memudahkan orang menabung, meminjam dan berinvestasi secara online (Wardhani, 2020).

Ketika rata-rata bisnis redup dihajar pandemi Covid-19, Fintech Lending atau peer to peer lending (P2P Lending) menjadi salah satu bisnis yang berkembang pesat di tengah pandemi Covid-19. Sepanjang tahun 2020, P2P alias pinjaman online mengalami pertumbuhan yang signifikan hingga 130 persen dibandingkan periode yang sama tahun sebelumnya (Novika, 2020). Akan tetapi di masa pandemi Covid-19 bisnis P2P lending tetap memiliki tantangan. Namun tantangan yang dihadapi harus disikapi sebagai peluang yang positif, salah satu peluangnya adalah pendanaan terhadap penggiat UMKM yang belum terkoneksi dengan perbankan.

Perusahaan Fintech syariah adalah perantara antara peminjam dan pelaku usaha dengan investor atau Institusi keuangan seperti Perbankan syariah, dan tidak menjadi pemberi modal seperti Fintech konvensional. Platform yang ditawarkan merupakan pembiayaan murah untuk UMKM yang menggunakan pendekatan "peer-to-peer lending marketplace". Konsep pembiayaan Fintech syariah ditentukan lewat akad yang sudah disepakati antara penerima dan pemberi pinjaman, dan akad yang disepakati berdasarkan peruntukan dana dari yang mengajukan pinjaman. Dalam Fintech syariah tidak ada bunga yang menjadi daya tarik dalam pembiyaan Fintech syariah.(Tim Media Informasi RISEF, 2019)

"Menurut CEO Bank Infaq Reza Arief Budy Artha mengungkapkan 99 persen pengusaha di Indonesia ada di kelas Mikro dan Kecil. Namun 78 persen UMKM tidak bisa mendapatkan permodalan dari lembaga keuangan formal seperti Bank". (Tempo.co, 2020) Imbasnya UMKM akan mendapatkan pinjaman dengan bunga ekstra tinggi. Dengan banyaknya pengusaha muslim yang menjadi pelaku UMKM, hal ini menjadi peluang untuk Fintech syariah berkembang pesat.

Menurut Sandi, pandemi Covid-19 ini menjadi peluang bagi Fintech syariah untuk mengembangkan platformnya karena akan lebih banyak pengusaha yang akan mencari pinjaman alternatif selain perbankan (Tempo.co, 2020). Dan ini didukung oleh program pemerintah yang terus-menerus mengembangkan Industri halal di Indonesia, di dukung dengan dibentuknya Komite Nasional Ekonomi dan Keuangan Syariah (KNEKS) pada tahun 2020 yang diketuai oleh Presiden RI Jokowi dan Wakil Presiden RI Ma'ruf Amin yang menjadi wakil ketua merangkap ketua harian KNEKS.

Direktur Jasa Keuangan Syariah KNEKS Taufik Hidayat mengungkapkan Indonesia yang 87 persen penduduknya adalah muslim menjadi konsumen besar produk halal dan pasar untuk produk-produk halal (Tempo.co, 2020). Menurut data dari Otoritas Jasa Keuangan (OJK) tahun 2019, investasi pada ekonomi syariah di bidang keuangan syariah menguasai 42 persen hampir separuh dari investasi syariah di Indonesia. Dan Indonesia diperkirakan akan mengalami pertumbuhan produk dan jasa halal di semua sektor sebesar 5.3 persen pada tahun 2025 (Tempo.co, 2020). 


\subsection{Fintech Syariah Jadi alternatif Solusi Permodalan UMKM di Masa Pandemi}

Permodalan adalah perrmasalahan yang dihadapi UMKM terutama di tengah wabah Covid-19 saat ini. Fintech syariah bisa menjadi solusi permodalan masyarakat khususnya UMKM agar bertahan di tengah pandemi ini untuk mempertahankan usaha dan beban operasionalnya.

Untuk menjawab tantangan tersebut, Financial technology (Fintech) syariah dapat dijadikan salah satu alternatif solusi oleh pelaku Usaha Mikro Kecil Dan Menengah (UMKM). terutama UMKM yang tidak memiliki kapasitas dan persyaratan cukup untuk mendapatkan pembiayaan perbankan, khususnya pembiayaan modal kerja. Selain itu penentuan bagi hasil akan dituangkan dalam akad yang sudah disepakati antara pemberi maupun penerima pinjaman. Adanya akad yang terukur ini akan menjadi nilai lebih bagi Fintech syariah.

Setidaknya ada 63 juta usaha mikro yang mungkin separuhnya unbankable, Fintech bisa membantu pengefektifan bantuan pembiayaan pemerintah dan sebagai parameter yang menunjukkan peningkatan literasi keuangan masyarakat, khususnya UMKM dalam mengakses pembiayaan serta transaksi keuangan. Hal ini didukung oleh data Otoritas Jasa Keuangan (OJK) dimana terjadi peningkatan di semua unsur terkait mulai dari perusahaan Fintech hingga penyaluran pinjaman yang mencapai Rp146,25 triliun pada Januari hingga November 2020 (Nurhaliza, 2021)

\section{Kesimpulan}

Penelitian ini menghasilkan kesimpulan bahwa selama masa Pandemi Covid-19 omset UMKM mengalami penurunan dan banyak UMKM yang tidak memiliki cadangan modal usaha. Terdapat tiga sektor yang paling terdampak akibat Covid-19 ini yaitu perdagangan besar dan eceran, reparasi mobil dan sepeda motor, sektor transportasi dan pergudangan, serta sektor penyediaan akomodasi dan makan minum yang mana banyak didominasi oleh UMKM. Fintech berupa P2P (Peer To Peer) lending adalah jawaban untuk penggiat UMKM yang Unbankable menjadi mudah terakses. Melalui Fintech bisa menghubungkan penggiat UMKM dengan layanan keuangan yang sebelumnya belum terjamah oleh layanan keuangan perbankan. Pada akhirnya, Fintech ini bisa meningkatkan kapasitas UMKM dan mengalami peningkatan. Fintech syariah bisa menjadi solusi permodalan masyarakat khususnya UMKM agar bertahan di tengah pandemi ini untuk mempertahankan usaha dan beban operasionalnya. Selain itu, Fintech bisa membantu pengefektifan bantuan pembiayaan pemerintah dan sebagai parameter yang menunjukkan peningkatan literasi keuangan masyarakat, khususnya UMKM dalam mengakses pembiayaan serta transaksi keuangan.

\section{Referensi}

Arifin, S. R., \& Wisudanto. (2017). Crowdfunding Sebagai Alternatif Pembiayaan Pembangunan. In UNIID 2017 (Vol. 2, Issue 1).

Ariyanti, F. (2019). Peran Penting Fintech Primadona' di Era Digital. Www.Cermati.Com. https://www.cermati.com/artikel/peran-penting-fintech-primadona-di-era-digital

Barus, K. (2021). Jumlah Penduduk Muslim Indonesia Meningkat, PowerCommerce Asia Tangkap Peluang, Luncurkan Halal Plaza. Www.Industry.Co.Id. https://www.industry.co.id/read/65748/jumlah-penduduk-muslim-indonesia-meningkatpowercommerce-asia-tangkap-peluang-luncurkan-halal-plaza 
Cakti, A. (Antara N. (2021). UNDP: Usaha mikro masib bergantung pada sumber pendanaan keluarga. Www.Antaranews.Com. https://www.antaranews.com/berita/1960468/undp-usahamikro-masih-bergantung-pada-sumber-pendanaan-keluarga

Darsono, \& Dkk. (2017). Masa Depan Keuangan Syariah Indonesia. Tazkia Publishing.

Evandio, A. (2020). AFSI Resmi Ditunjuk OJK Sebagai Payung Bagi Penyelenggara Fintech Syariah. Finansial.Bisnis.Com. https:// finansial.bisnis.com/read/20200824/563/1282420/afsiresmi-ditunjuk-ojk-sebagai-payung-bagi-penyelenggara-fintech-syariah

Fachrizal, R. (2019). Terdaftar di OJK, Inilab Deretan Fintech Syariah di Indonesia. Infokomputer.Grid.Id. https://infokomputer.grid.id/read/121852524/terdaftar-di-ojkinilah-deretan-fintech-syariah-di-indonesia?page $=$ all

Keuangan, O. J. (2021). Penyelenggara Fintech Lending Terdaftar dan Berizin di OJK per 30 Maret 2021. Www.Ojk.Go.Id. https://www.ojk.go.id/id/kanal/iknb/financialtechnology/Pages/Penyelenggara-Fintech-Lending-Terdaftar-dan-Berizin-di-OJK-per-30Maret-2021.aspx

Novika, S. (2020). Pinjaman Online ke Fintech Meroket di Masa Pandemi. Finance.Detik.Com. https:// finance.detik.com/fintech/d-5158115/pinjaman-online-ke-fintech-meroket-dimasa-pandemi

Nurhaliza, S. (2021). UMKM Kesulitan Modal, Fintech Jadi Solusi di Tengah Pandemi. Www.Idxchannel.Com. https://www.idxchannel.com/market-news/umkm-kesulitanmodal-fintech-jadi-solusi-di-tengah-pandemi

Rahmawati, L., Rahayu, D. D., Nivanty, H., \& Lutfiah, W. (2020). Fintech Syariah : Manfaat dan Problematika Penerapan Pada UMKM. Masharif Al-Syariah, 5(1). https://doi.org/doi.org/10.36778/jesya.v3i1.132.

Rakyat, K. U. (2020). Perubahan Kebijakan Kredit Usaha Rakyat (KUR) Tabun 2020. Kur.Ekon.Go.Id. https://kur.ekon.go.id/perubahan-kebijakan-kredit-usaha-rakyat-kurtahun-2020

Rizal, M., Maulina, E., \& Maulina, E. (2019). Fintech Sebagai Salah Satu Solusi Pembiayaan Bagi UMKM. AdBispreneur, 3(1). https://doi.org/10.24198/adbispreneur.v3i2.17836

Rizky, M., \& Kencana, B. (2020). Menteri Teten: Nasib UMKM Tergantung pada Penanganan Covid19. Www.Merdeka.Com. https://www.merdeka.com/uang/menteri-teten-nasib-umkmtergantung-pada-penanganan-Covid-19.html

Simanjorang, S. (2020). Nasib UMKM di Tengah Pandemi Covid-19. Investor.Id. https://investor.id/opinion/nasib-umkm-di-tengah-pandemi-covid19

Techfor Id. (2019). Ini Dia Manfaat Fintech Syariah Untuk Pemberdayaan Ekonomi Umat. Www.Techfor.Id. https://www.techfor.id/ini-dia-manfaat-fintech-syariah-untukpemberdayaan-ekonomi-umat/\#comments

Tempo.co. (2020). Sandiaga Uno: Fintech Syariah Harusnya Jadi Solusi untuk UMKM. Www.Msn.Com. https://www.msn.com/id-id/ekonomi/bisnis/sandiaga-uno-fintechsyariah-harusnya-jadi-solusi-untuk-umkm/ar-BB1blVat

Tim Media Informasi RISEF. (2019). Fintech Syariah, Jawaban Permodalan tanpa Riba. Bagaimana? Ps.Febi.Radenintan.Ac.Id. https://ps.febi.radenintan.ac.id/karya-mahasiswa/fintechsyariah-jawaban-permodalan-tanpa-riba-bagaimana/

Tripalupi, R. I., \& Anggahegari, P. (2020). The Impact of Covid-19 Pandemic: Challenges and Opportunities of Syariah Financial Technology. International Journal of Nusantara Islam, 8(1), 119-128. https://doi.org/10.15575/ijni.v8i1.10207

Wardhani, N. K. (2020). Bagaimana fintech dapat membantu usaha kecil dan menengah Indonesia bertaban dari pandemi COVID-19. Theconversation.Com. 
https://theconversation.com/bagaimana-fintech-dapat-membantu-usaha-kecil-danmenengah-indonesia-bertahan-dari-pandemi-Covid-19-149431

Yoga, P. (2020). Krisis Ekonomi Akibat Covid-19 Gencet Segmen UMKM. Infobanknews.Com. https://infobanknews.com/topnews/krisis-ekonomi-akibat-Covid-19-gencet-segmenumkm/ 